\title{
The effect of gestation and lactation of dairy cows on lipid and lipoprotein patterns and composition in serum during winter and summer feeding
}

\author{
B. Pysera and A. Opalka \\ Institute of Animal Nutrition and Feed Management, \\ University of Warmia and Mazturia in Olsztyn \\ Oczapowskiego 5. 10-718 Olsztyn, Poland
}

(Received 19 April 1999; accepted 15 July 2000)

\section{$\triangle B S T R \Lambda C T$}

Studies werc carried out on lipid and lipoprotein fractions in the serum of cows during summer and winter feeding. The experimental group comprised 32 Black-and-White cows in the final stage of pregnancy (2-3 weeks before calving) or in the 6th week of lactation.

Total serum lipid $(2.51 \mathrm{~g} / \mathrm{l})$ and cholesterol $(2.51 \mathrm{mmol} / \mathrm{l})$ concentrations were significantly lower $(\mathrm{P}<0.01)$ in cows subjected to drying than in lactating animals $(3.29 \mathrm{~g} / \mathrm{l}$ and $3.86 \mathrm{mmol} / \mathrm{l}$, respectively), irrespective of the feeding period. In contrast, the serum triglycerides concentration was 0.34 $\mathrm{mmol} / \mathrm{l}$ in cows before calving and twice as high than during lactation. It was also shown that HDL constituted the main fraction, and that HDL in cows prior to calving represented about $74 \%$ of serum lipids, increasing to about $80-85 \%$ during lactation. The LDL concentration was lower, representing, on average, $22 \%$ in dry cows, and $13-15 \%$ in the 6 th week of lactation. Prior to calving, triglycerides represented over $40 \%$ of LDL, $32 \%$ was represented by cholesterol. In the peak of lactation the TG fraction in LDL decreased to $14-19 \%$, white that of cholesterol increased to over $45 \%$.

KEY WORDS: dairy cow, blood serum, lipids, lipoproteins

\section{INTRODUCTION}

Lipids are transported in blood by lipoproteins, which are lipid-protein complexes. Lipoprotcins are characterised by different structures, places of origin and physiological functions, depending on the share of specific proteins.

Secretion and composition of lipoproteins in ruminants are the main factors controlling lipid metabolism in tissues and organs (Bauchart, 1993). Lipoproteins 
in cows play a special role in milk fat synthesis (Grummer, 1993; Yamamoto et al., 1995; Fujita et al., 1996), but they also affect steroidogenesis (Kampl et al., 1990; Hawkins et al., 1995).

Cattle lipoprotein fractions have been defined as VLDL, LDL and HDL. Very low density lipoproteins (VLDL, $\mathrm{d}=0.950-1.006 \mathrm{~g} / \mathrm{ml}$ ) transport mainly endogenic triglycerides synthesized in the liver. Cow liver capacity to secrete triglycerides in VLDL is regarded as very low compared to its ability to take up and esterify fatty acids (Mazur et al., 1988). Generally, less than $1 \%$ of serum lipids circulate in the VLDL fraction of lactating cows (Schweigert, 1990). It is assumed that low density lipoproteins (LDL, $\mathrm{d}=1.006-1.068 \mathrm{~g} / \mathrm{ml}$ ) and high density lipoproteins (HDL, $\mathrm{d}=1.068-1,21 \mathrm{~g} / \mathrm{ml}$ ) constitute the major lipoprotein fractions in cows (Mazur et al., 1988; Schweigert, 1990). Their composition, distribution and metabolism are not constant and have not been fully defined as yet. These parameters can be modificd by cow physiology and quality of fecds (Mazur et al., 1988; Schweigert, 1990; Van Den Top et al., 1995; Fujita et al., 1996). Mazur et al. (1988) and Özpinar et al. (1988) determined the concentration of VLDL and LDL fractions in cows 2 and 6 weeks after calving and found an invariably low level of VLDL and an increase in LDL lipoproteins. The lipid composition of the LDL fraction was also modified; the cholesterol level at the beginning of lactation was almost 3 times lower than 6 weeks after calving (Mazur et al., 1988). In other studies (Van Den Top et al., 1995) the LDL level did not change between the end of pregnancy and the initial phase of lactation, while there was an increase of HDL lipoproteins. A similarly increased level of HDL at the peak of lactation was observed by Fujita et al. (1996), and the amounts of circulating HDL as well as LDL were higher in autumn than in summer.

The small number of studies conducted on the subject reveal that low feeding levels may decrease lipoprotein concentrations (Fujita et al., 1996), while various feed additives have different effects on lipoprotein metabolism (Durand et al., 1992; Sklan et al., 1994; Burke et al., 1996). Intravenous infusions of methionine (Durand et al., 1992) to lactating cows favoured hepatic LDL secretion, but did not affect scrum cholesterol and LDL levels. Addition of cholesterol to tallow- or soyabean oil-rich diets did not modify VLDL metabolism, but increased the plasma concentration of LDL (Bauchart et al., 1996). According to some authors (Bauchart et al., 1996, Burke et al., 1996) polyunsaturated fatty acids of the diet, especially linoleic acid, not only did not lower, but increased hypercholesterolaemia in cows. On the other hand, other studies (Sklan et al., 1994) showed that an addition of protected fats in the form of fatty acid calcium soaps did not change the cholesterol concentration in the scrum of cows.

The results of studies carried out to date do not give an unequivocal answer as to which factors affect lipoprotein metabolism in cows. Moreover, the majority of available data (Mazur et al., 1988; Schweigert, 1990; Durand et al., 1992; Van Den 
Top et al., 1995; Fujita et al., 1996) originated from model cxperiments, and not from studies carried out under conditions of commercial farming.

In view of this, studies were undertaken to determine the dependence betwcen late gestation and peak lactation and the content of some lipid classes, LDL and HDL lipoprotein fractions, in serum during summer and winter feeding.

\section{MATERIAL AND METHODS}

\section{Animals and feeding}

Studies were performed on multiparous Black-and-White cows of averagc body weight $518( \pm 29.3) \mathrm{kg}, 4^{\text {th }}-6^{\text {th }}$ lactation, during summer and winter feeding ( $4 \times 8$ cows). The mean milk production of the cows was $4300 \mathrm{~kg}$ for 305 days of lactation. The study encompassed dairy cows 14-20 days prior to calving (dry cows) and 38-42 days after calving (lactating cows).

In the summer, the cows grazed on pasture (May-July), and their diet was supplemented with ground grain mixture $(1.6 \mathrm{~kg})$, or they were given meadow hay $(3 \mathrm{~kg}$, in August-Octobcr) and a mixture of ground grain $(3 \mathrm{~kg})$. The amount of consumed pasture grass was estimated based on the analytical method by Różycki (intake of grass was predicted once daily from data according to control fields before and after grazing). The cows received fodder straw from oat ad libitum throughout the summer feeding period. In winter the animals were fed a diet containing wilted grass silage $(20 \mathrm{~kg})$, meadow hay $(3 \mathrm{~kg})$ and a mixture of ground grain $(3 \mathrm{~kg})$. Feed rations for the cows were balanced according to traditional Polish standards (Chomyszyn et al., 1993). When milk production exceeded $14 \mathrm{~kg}$ per day, the diet was supplemented with $0.5 \mathrm{~kg}$ of a ground grain mixture per $\mathrm{kg}$ of milk. The composition of the cercal mixture was $(\%)$ : ground wheat 35 , ground oats 35 , ground barley 27 , fodder phosphate 1 , limestone 1 , salt 0.5 , and premix B 0.5 .

\section{Sampling procedures and analytical methods}

Blood was examined in May/June and September/October (summer feeding), and in December/January and March/April (winter feeding). Blood samples werc collected from the jugular vein before the morning feeding. Serum was separated by centrifugation at $3000 \mathrm{x}$ g for $30 \mathrm{~min}$. After centrifugation, $0.02 \%$ EDTA was added to serum samples. All samples were stored at $4^{\circ} \mathrm{C}$.

Lipoprotcin fractions (LDL and HDL) were separated by flotation in a sodium bromide $(\mathrm{NaBr})$ gradient, using ultracentrifugation at $5^{\circ} \mathrm{C}$ (Beckman L7-55, type 50.3 Ti-rotor), according to the method described by Mills et al. (1989). Low den- 
sity lipoproteins (LDL, $\mathrm{d}=1.006-1.068 \mathrm{~g} / \mathrm{ml}$ ) were centrifuged at $140000 \mathrm{x} \mathrm{g}$ for $24 \mathrm{~h}$. High density lipoprotcins (HDL, $\mathrm{d}=1.068-1.210 \mathrm{~g} / \mathrm{ml}$ ) were isolated for $48 \mathrm{~h}$ at $140000 \mathrm{x}$.

Total lipid content was determined in the scrum and in LDL and HDL fractions using a „Biochemtest” diagnostic test (Poland, Cat. No. 178212 144). Total cholesterol and triglycerides (TG) were determined using enzymatic methods with tests produced by Alpha Diagnostics (Poland, Cat. No. C6509-400 and T6531-400).

The chemical composition of the feeds was determined using conventional methods.

\section{Statistical analysis}

The results were analysed with the variance method in an orthogonal bifactorial system, and multiple range Duncan's test using the Statgraphics program (ver. $2.61985 / 87)$.

\section{RESULTS}

The diet (DM) consisted of $68-77 \%$ forages and $32-23 \%$ concentrates. The chemical composition of feeds and nutritive value of daily rations are presented in Tables 1 and 2.

Analysis of nutrient concentration in dry matter of the daily rations showed that the level of energy (MJ) was similar (Table 2). On the other hand, the crude protein content in the initial phase of summer feeding (May-July) was higher than the protcin requirements of cows according to Polish standards (Chomyszyn et al., 1993).

TABLE 1

Chemical composition of feeds, $\%$

\begin{tabular}{lcccccc}
\hline Feeds & $\begin{array}{c}\text { Dry matter } \\
\text { (DM) }\end{array}$ & Ash & $\begin{array}{c}\text { Crude } \\
\text { protein }\end{array}$ & $\begin{array}{c}\text { Ether } \\
\text { extract }\end{array}$ & $\begin{array}{c}\text { Crude } \\
\text { fibre }\end{array}$ & $\begin{array}{c}\text { NE }^{l}, \\
\text { MJ }\end{array}$ \\
\hline Pasture grass $^{3}$ & 21.3 & 2.19 & 3.69 & 0.85 & 4.58 & 1.19 \\
Pasture grass $^{3}$ & 22.6 & 2.29 & 3.31 & 0.91 & 5.43 & 1.30 \\
Grass silage & 35.7 & 3.35 & 5.40 & 1.75 & 10.80 & 2.20 \\
Meadow hay & 87.5 & 7.61 & 10.06 & 2.12 & 26.13 & 3.20 \\
Cereal mixture & 87.9 & 6.91 & 11.50 & 2.35 & 6.22 & 6.20 \\
\hline
\end{tabular}

$1 \mathrm{NE}$ - nct energy (MJ) calculated from starch value

${ }^{2.3}$ pasture grass was analysed in June ${ }^{2}$ and September ${ }^{3}$ 
TABLE 2

Fecd intake, nutritive value and nutrient supply of daily diets during summer and winter feeding

\begin{tabular}{lccc}
\hline \multirow{2}{*}{ Item } & \multicolumn{2}{c}{ Summer feeding } & Winter feeding \\
\cline { 2 - 3 } & May - July & August - October & November - April \\
\hline Intakc of kg DM/day & 10.7 & 6.8 & 7.2 \\
pasture grass & - & - & 2.6 \\
grass silage & - & 2.6 & 4.4 \\
meadow hay & 3.2 & 4.4 & 14.2 \\
compound mixture & 13.9 & 13.8 & \\
total & & & 13.8 \\
& 16.2 & 13.5 & 3.7 \\
Nutritive value, in DM & 3.4 & 3.2 & 22.9 \\
crude protein, \% & 18.0 & 19.7 & 6.0 \\
ether extract, \% & 6.0 & 5.9 & \\
crude fibre, \% & & & 1955 \\
NE, MJ/kg DM & & & 526 \\
Nutrient supply: & 2252 & 4865 & 3253 \\
crude protein, g/d & 474 & 2713 & 84.6 \\
ether extract, g/d & 2508 & 81.4 & \\
crude fibre, g/d & 83.8 & & \\
NE, MJ' & & & \\
\hline
\end{tabular}

I see Table 1

The concentration of total scrum lipids of dry cows was highly significantly lower (by $25 \%$ on average) than in cows in the 6th week of lactation, irrespective of the fecding period (Table 3 ). The total cholesterol concentration was $34 \%$ lower before calving, while TG levels in dry cows were almost two times higher than during lactation.

Lipoprotein fractions separated by ultracentrifugation showed that HDL was the major fraction of serum of dairy cows, LDL was present in much lower levels (Figure 1). The concentration of lipoproteins differed during pregnancy and lactation, with more pronounced changes observed in the LDL fraction. In cows before calving, this fraction transported $22 \%$ of serum lipids on the average, while in the 6 th week of lactation it transported 13-15\%. The HDL fraction was lower (by $12 \%$ on average) in dry cows compared with the concentration found at the peak of lactation.

It was also shown that apart from quantitative changes, the lipid composition of lipoproteins also depended on the physiological state of the animal. In cows before calving, TG constituted over $40 \%$ of the LDL, irrespective of the feeding period (Table 4). At the peak of lactation, the TG fraction of LDL decreased to $16 \%$, on average. In contrast, the cholesterol fraction in LDL was significantly lower in dry 
至

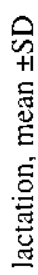

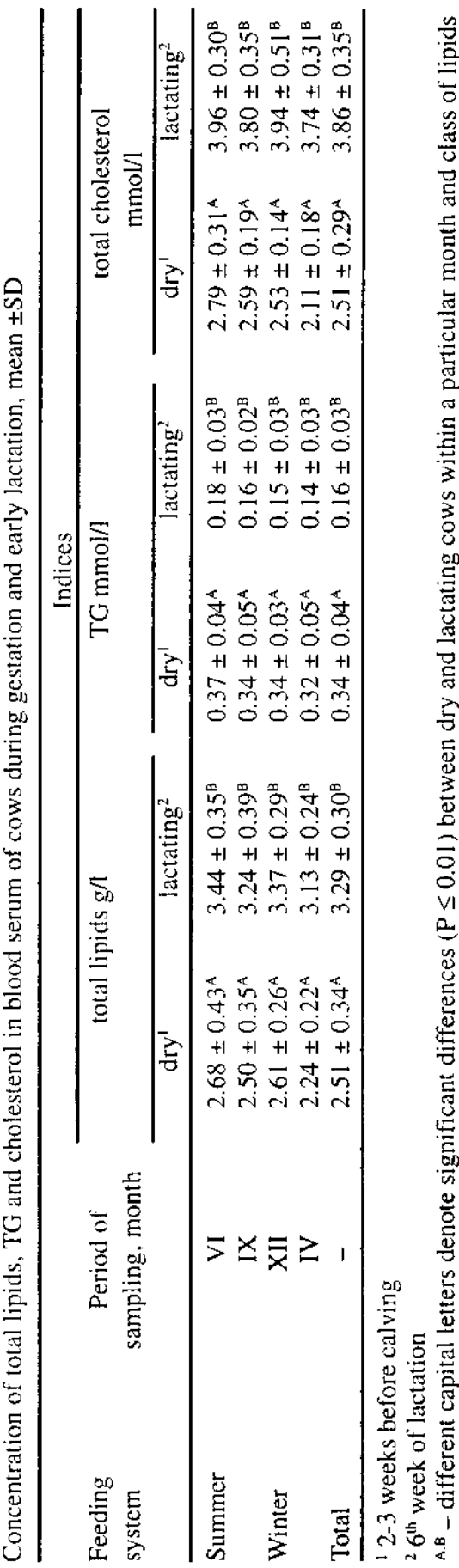

药

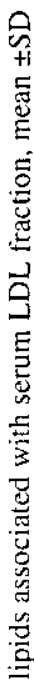

害

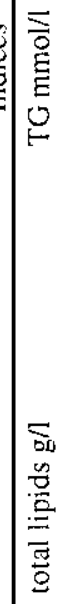

然

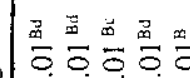

$\approx 000$

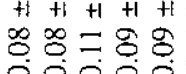

-

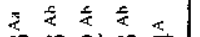

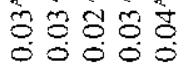

$\begin{array}{lll}n+1 & +1 & +1 \\ 0 & +1\end{array}$

ำ 둬ำ

잉 0.

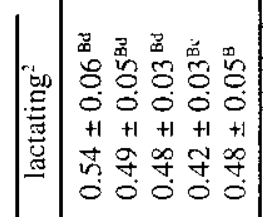

금

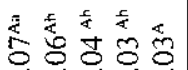
0000

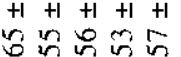

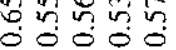

|

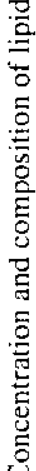

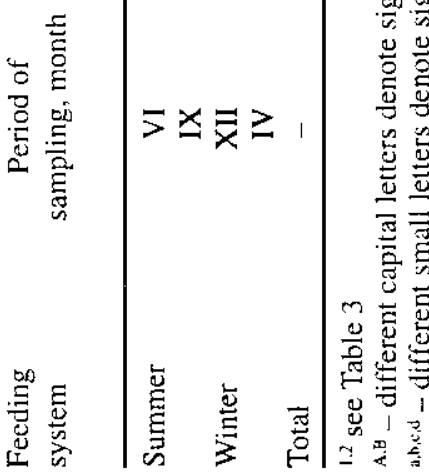




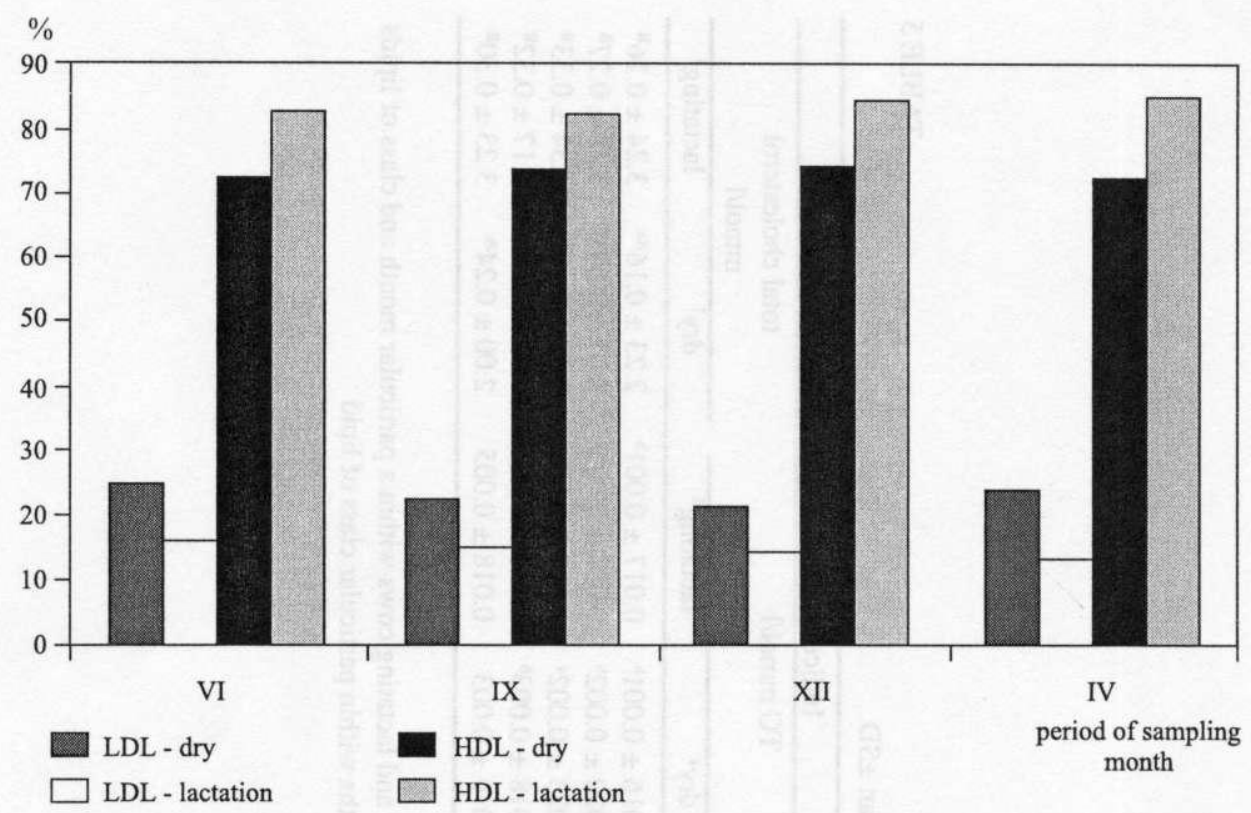

Figure 1. Average relative percent of LDL and HDL in serum lipoproteins

cows, making up, on average, $32 \%$ of LDL. In lactating cows the LDL cholesterol concentration increased to over $45 \%$.

The differences in the lipid composition of the HDL fraction were not very pronounced (Table 5). Triglycerides represented about $1 \%$ of HDL irrespective of the physiological state of dairy cows; this is three times above the detection level. Cholesterol was the major lipid, constituting $42-45 \%$ of HDL.

\section{DISCUSSION}

The results obtained in this study are in agreement with other authors (Kampl et al., 1990; Damnjanovič et al., 1993; Bronicki and Dembiński, 1995a,b; Van Den Top et al., 1995; Máchal et al., 1996) and suggest that the lipid profiles in dairy cows before and after calving differ considerably. This difference was reflected not only in different total serum lipid concentrations in the animals before calving and at the peak of lactation, but also in lipid composition. Other authors have reported increases in total plasma lipid levels in cows during lactation (Kampl et al., 1990; Máchal et al., 1996). Kampl et al. (1990) found a correlation between the serum total lipid value and the development of lactation. However, the highest positive correlation was found at the end of the first month of lactation. 
造

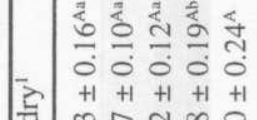

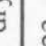

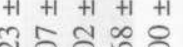

4 n

늘

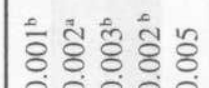

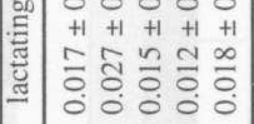

$\lesssim \quad-$

00000

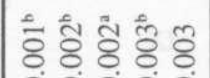

氙

믈

羟

is 路

ठ

का

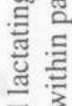

- $1+1+1+1+1$

코

는

ป

를

3

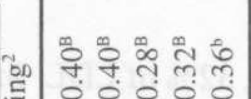

8

全

:

(1)

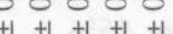

ํำ

i n i cici

VI ${ }_{\text {VI }}$

e

\&

:

एँ

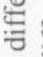

돈

00000

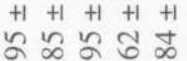

- -

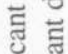

送

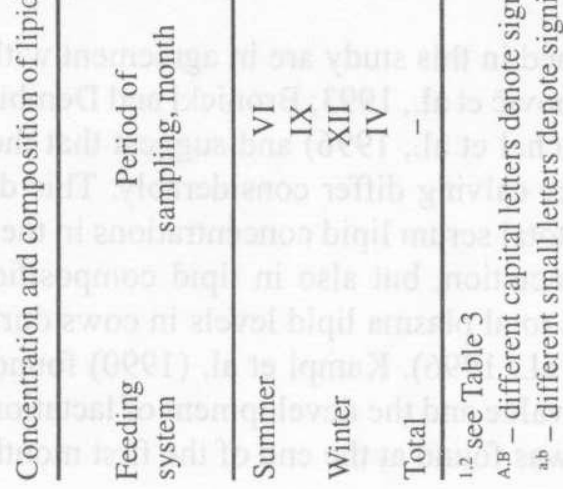


The high TG concentration observed 2-3 weeks before calving and the steep fall afterwards suggests that TG play an important role in the synthesis of milk fat (Table 3). Other authors have also observed a decrease of serum TG levels after calving (Schweigert, 1990; Grummer, 1993; Bronicki and Dembiński, 1994; Yamamoto et al., 1995). The high requirements of the mammary gland for lipids may be met by an increase of free fatty acids, which is associated with a decrease in TG levels (Vazquez-Anon ct al., 1994). Many authors assume that the ratio between free fatty acids and TG can be used as an index of lipid retention in the liver, reflecting disturbances in fat metabolism (Holtenius, 1989; Bronicki and Dembinski, 1995a) and causing irreversible fatty degradation of the liver (Andrews et al., 1991; Bronicki and Dembiński, 1998). Given that fat metabolism is strictly related to hormone activity (Bronicki and Dembiński, 1995b; Hawkins et al., 1995), these changes lead to disturbances in cholesterol biosynthesis by the liver and in steroid transformations, negatively affecting a cow's fertility and health after calving.

It can be assumed that the observed significant increase of cholesterol levels in lactating cows compared with the period before calving was related to increased requircments for cholesterol of the glands producing steroid hormones. This suggestion is confirmed by the studies of Mazur ct al. (1988), Kampl et al. (1990), Schweigert (1990), Bronicki and Dembiński (1995b), and Van Den Top et al. (1996) who observed the lowest cholesterol levels in the calving period, followed by a systematic increase of its concentration, up to a peak value 6-8 weeks after calving. These changes of cholesterol concentration in the blood serum of cows were observed in animals with no clear symptoms of lipid metabolism disturbances (Doležal et al., 1991; Máchal ct al., 1996). In cows suffering from impaired liver function, the concentration of total lipids and total cholesterol in serum was lower (Kampl et al., 1990; Máchal et al., 1996).

It is interesting that there were no noticeable differences in lipid levels between the summer and winter fecding periods. This might have resulted from the diets having been based on either green forages (pasture) or conserved feedstuffs (grass silage and hay). The daily ration (DM) consisted of $68-77 \%$ forages. In addition to this, a feed mixture of the same composition was used throughout the entire experiment. Although the share of mixture I during basic feeding (May-July) represented $23 \%$ of the dry feed dose, and $32 \%$ in the other periods, rations were characterised by a similar content of crude fat. Its concentration in DM of the dict was from 3.2 to $3.7 \%$. It scems that this factor could not have significantly differentiated lipid levels in the scrum of cows. This is confirmed by a variable effect of added fat in cow diets on the level of some lipids in serum. Sklan et al. (1994) did not find any effect of added fat on cholcsterol levels. In other studies (Marty and Block, 1992; Burke et al., 1996), addition of fat increased the cholesterol concentration. The reasons for these discrepancies are unknown. On the other hand, adding fat 
usually increases the serum TG level (Marty and Block, 1992; Sklan et al., 1994). Given that in out study feed rations were not modified with any additives, lipid metabolism was affected more by late pregnancy and pcak of lactation. This suggestion is supported by the pattern of lipoprotein changes in the serum. Irrespective of the feeding period, the LDL and HDL fractions were noticeably different in the dry period and at peak of lactation. LDL decreased significantly in lactating cows. Schweigert (1990) also examined lipoproteins in dairy cows and observed a rapid decrease of the LDL fraction from over $20 \%$ before delivery to only $4 \%$ at calving. LDL during lactation increased, however; by 6 weeks after calving the LDL level was $25 \%$ lower than during pregnancy. Becausc lipid and lipoprotein levels were determined in each cow only two times (2-3 weeks before calving and 6 wecks after calving), it was not possible to observe this rapid decrease of LDL during calving. This, however, does not change the fact that the LDL fraction changes noticeably in cows in the calving period (Özpinar ct al., 1988; Kampl et al., 1995). The decrease in LDL levets may be compared with the changes in the Ig G1 fraction in the serum of cows during calving (Schwcigert, 1990).

In contrast with the LDL level, the HDL concentration in lactating cows was significantly higher than in dry animals. According to Van Den Top ct al. (1995) an increase in HDL concentration should reflect changes taking place in the levels of VLDL. Their catabolism is associated with the transfer of surface material (free cholesterol, phospho-lipids and Apo-C) to HDL. Although VLDL were not determined in this study, it was roughly assessed that their percentage was low and in cows before calving VLDL may comprise about $4 \%$ of scrum lipids, while their percentage during lactation only about $1 \%$. Studics by Schwcigert (1990) suggest that the VLDL concentration in cows 3-4 weeks before calving represented some $3 \%$ of serum lipids, and increased to $5 \%$ a week before delivery, to decrease again to less than $1 \%$, remaining on this low level throughout lactation. Mazur et al. (1988), Özpinar ct al. (1988) and Van Den Top ct al. (1995) observed similar changes in VLDL levels during pregnancy and lactation in cows. The lack of differences in lipoprotein levels in summer and winter observed in this study does not confirm the conclusions of Fujita et al. (1996) on higher amounts of circulating LDL and HDL during lactation in autumn than in summer. According to these authors, these differences resulted from decreased metabolic activity in summcr, caused by higher temperatures.

Data on the lipid composition of lipoproteins secm interesting. HDL composition was only slightly modified by the physiological state of cows or feeding system. The high percentage of cholesterol in this fraction confirms the results of Van Den Top et al. (1995) and Herdt and Smith (1996) that 80-90\% of serum cholesterol was transported in dairy cows by HDL molecules. The LDL fraction showed more pronounced changes during gestation and lactation. Different concentrations of TG and cholesterol in dry and lactating cows seem to be reflected in their levels 
in the LDL fraction. TG accounted for over $40 \%$ of the LDL fraction in dry cows. Similarly, a higher level of TG in the LDL fraction in the antepartum period and a lower level during lactation were found by Bobowice et al. (1997), while in peak of lactation the main lipid in the LDL fraction was cholesterol (over $45 \%$ ). In view of these data it may be suggested (Schweigert, 1990) that the LDL fraction plays a key role in cholesterol metabolism. Cholesterol bound to LDL molecules is an important source of this lipid for all cells of the body. Studies in vitro as well as in vivo showed that inhibition of cholesterol supply to the steroid-producing glands, caused by a decrease in LDL, resulted in lower synthesis of steroid hormones. Hawkins et al. (1995) suggested that due to progesterone deficiency, abortions may reach lcvels as high as $20-45 \%$ in ruminants.

The quantitative and qualitative changes in the LDL fraction observed in our experiment confirm the concept (Mazur et al., 1988; Schweigert, 1990) that metabolic disturbances after calving and fertility problems in cows may be related to the time required by the animal for its LDL concentration to increase to its normal level.

\section{CONCLUSIONS}

The obtained results revealed that in the calving period of cows, the pattern of lipid changes was subject to considerable variations independent of the feeding system. This was reflected not only in the serum lipid concentration, but also in the profile of the lipoprotein fraction.

The proportions and composition of the lipoprotein fraction of LDL and HDL depended most of all on the physiological state of the cows, with pregnancy and lactation having a more pronounced effect on quantitative and qualitative changes of LDL lipoproteins.

\section{REFERENCES}

Andrews A.H., Laven R., Maisey 1., 1991. Treatment and control of an outbreak of fat cow syndrome in a large dairy herd. Vet. Rec. 129, 216-219

Bauchart D., 1993. Lipid absorption and transport in ruminants. J. Dairy Sci. 76, 3864-3881

Bauchart D., Gruffat D., Durand D., 1996. Lipid absorption and hepatic metabolism in ruminants. Proc. Nutr. Soc. 55, 39-47

Bobowiec R., Filar R., Marczuk J., Kosior U., 1997. Periparturient changes in plasma lipoprotein composition of dairy cows (in Polish). Med. wet. 53, 734-738

Bronicki M., Dembiński Z., 1994. Studies on the activity of selected hepatic enzymes in dairy cows in conjunction with lipid metabolism markers (in Polish). Med. wet. 50, 268-271 
Bronicki M., Dembiński Z., 1995a. The activity of selected liver enzymes in dairy cows with different degree of disturbed lipid metabolism (in Polish). Zesz. Nauk. AR Stczec. Ser. Zoot. 166, 67-74

Bronicki M., Dembiński Z., 1995b. The effect of lipid metabolism disturbances in cows during calving on the activity of ovaries determined as progesterone levels in blood (in Polish). Med. wet. 51, 604-606

Bronicki M., Dembinski Z., 1998. Diagnosis and prognosis of liver changes in course of fatty degeneration in dairy cows (in Polish). Med. wet. 54, 598-600

Burke J.M.. Carroll D.J., Rowe K.E., Thatcher W.W., Stormshak F., 1996. Intravascular infusion of lipid into ewes stimulates production of progesterone and prostaglandin. Biol. Reprod. 55. $169-175$

Chomyszyn M., Strzetelski J., Laszczka A., 1993. Nutrient requirements of cattle. In: Catte and Sheep Traditional Fecding Standards. R. Ryś (Editor). Research Institute of Animal Production. Kraków (Poland), pp. 5-28

Damnjanović Z., Šamanc H.. Jovanović M. J., Marković S., 1993. Lipid, lipoprotein and glucose concentration in blood serum of healthy and ketotic cows (in Croatian). Vet. Glasnik $47,335-344$

Doležal R., Kudlač E., Studenčik B., Balaštik J., 1991. Biochemical changes in peripheral blood parameters in cows within 45 days after parturition (in C7ech). Vet. Med. 36. 265-271

Durand D., Chilliard Y., Bauchart D., 1992. Effects of lysine and methionine on in vivo hepatic secretion of VLDL in the high yielding dairy cow. J. Dairy Sci. 75, Suppl. 1, 279 (Abstr.)

Fujita M.. Harada K., Yamashiro H., Kubota H., Yamamoto S.. 1996. Differece in profiles of circulating lipoproteins and thyroid hormones in milking cows between the autumn and the summer. Jap. Anim. Sci. Tech. 67, 519-525

Grummer R.R., 1993. Etiology of lipid-related metabolic disorders in periparturient dairy cows. J. Dairy Sci. $76,3882-3896$

Hawkins D.E., Niswender K.D., Oss G.M., Moeller C.L., Odde K.G., Sawyer H.R., Niswender G.D., 1995. An increase in serum lipids increases luteal lipid content and alters the disappearance rate of progesterone in cows. J. Anim. Sci. 73, 541-545

Herdt T.H., Smith J.C.. 1996. Blood-lipid and lactation-stage factors affecting serum vitamin E concentrations and vitamin $\mathrm{E}$ cholesterol ratios in dairy cattle. J. Vet. Diagn. Invest. 8. 228-232

Holtenius P.. 1989. Plasma lipids in normal cows around partus and in cows with metabolic disorders and without fatty liver. Acta Vet. Scand. 30, 441-445

Kampl B., Martinčić T., Catinclli M., Susnjič M.. 1990. Profiles of selected biochemical blood parameters in dairy cows during gravidity and lactation and their influence on milk production and reproductive efficiency. I. Total lipids and total cholesterol and its fractions in blood. Vet. Arhiv. 60, 293-305

Kampl B., Zdelar F., Pracny G., Martinčić T., 1995. Relationship between concentrations of fat in milk, and very low density lipoproteins cholesterol fraction in blood and incidence of productive diseases in dairy cows. Vet. Arhiv. 65, 149-154

Máchal L., Gerža M., Doležal P., 1996. Blood plasma lipemia in the post partum period in cows in relation to their conception (in Czech). Živoč. Výroba 41, 5-8

Marty B.J., Block E., 1992. Effects of dietary fat supplementation and recombinant bovine somatorropin and milk production, nutritional status and lipid metabolism of dairy cow. Can. J. Anim. Sci. $72,633-649$

Mazur A.. Gueux E., Chilliard Y.. Rayssiguier Y., 1988. Changes in plasma lipoproteins and liver fat content in dairy cows during early lactation. J. Anim. Physiol. Anim. Nutr. 59, 233-237 
Mills G.C., Lane P.A.. Weech P.K., 1989. A guidebook to lipoprotcin techniques. In: R.H. Burdon, P.H. Van Knippenberg (Editors). Laboratory Techniques in Biochemistry and Molecular Biology. Vol. 14. Elsevier Sci. Publishing, New York

Özpinar H.. Schweigert F.J., Özpinar A., Wierich M., Senel H.S., 1988. Änderung der Verteiłung der fettlöslichen Vitamine auf die Lipoproteinfraktionen bei Saugkälbern und Kühen in Abhängigkeit von der Geburt. Berl. Münch. Tierärztl. Wschr. 101, 383-387

Schweigert F.J., 1990. Effect of gestation and lactation on lipoprotein pattern and composition in dairy cows. J. Anim. Physiol. Anim. Nurt. 63, 75-83

Sklan D.. Kaim M.. Moa!lem U., Folman Y., 1994. Effect of dietary calcium soaps on milk yield, hody weight, reproductive hormones, and fertility in first parity and older cows. J. Dairy Sci. 77, 1652-1660

Van Den Top A.M., Wensing T., Geelen M.J.H., Wentink G.H., Van't Klooster A.T., Beynen A.C., 1995. Time trends of plasma lipids and enzymes synthesizing hepatic triacylglycerol during postpartum development of fatty liver in dairy cows. J. Dairy Sci. 78, 2208-2220

Van Den Top A.M., Geelen M.J.H., Wensing T., Wentink G.H., Van't Klooster A.T., Beynen A.C., 1996. Higher postpartum hepatic triacylglycerol concentrations in dairy cows with free rather than restricted access to feed during the dry period are associated with lower activities of hepatic glycerolphosphate acyltransterase. J. Nutr. 126, 76-85

Vasquez-Anon M., Bertics S., Luck M., Grummer R.R., 1994. Peripartum liver triglyceride and plasma metabolites in dairy cows. J. Dairy Sci. 77, 1521-1528

Yamamoto O., Oikawa S., Katoh N., 1995. Enzyme-linked immunosorbent assay for serum apolipoprotein B-100. a major trigriceryde - transport protein in dairy cows. Amer. J. Vet. Res. 56. $1413-14 ! 7$

\section{STRESZCZENIE}

\section{Wplyw okresu ciąży i laktacji na sklad lipidów i lipoprotein w surowicy krwi krów w okresie zywienia letniego i zimowego}

W surowicy krwi 32 krów cb w końcowym okresic ciąży (2-3 tyg. przed porodem) oraz w 6 tygodniu laktacji, podczas żywienia letniego i zimowego, oznaczano stężenie niektórych frakcji lipidowych i lipoprotcin. Niczalcżnic od okresu żywienia stężenia całkowitych lipidów $(2,51 \mathrm{~g} / \mathrm{l})$ i cholesterolu $(2,51 \mathrm{mmol} / \mathrm{l})$ bylo istotnie niższe $(\mathrm{P}<0,01)$ w surowicy krów zasuszonych niż krów produkujących mleko $(3,29 \mathrm{~g} / \mathrm{l}$ i $3,86 \mathrm{mmol} / \mathrm{t}$, odpowiednio). Stężenie trójglicerydów w surowicy krów przed porodem wynosiło $0,34 \mathrm{mmol} / \mathrm{l}$ było ponad dwukrotnie wyższe niż w okresie laktacji. Stwierdzono także, że u krów frakcje lipoprotein o wysokicj gęstości (HDL) stanowią główną frakcję lipidów surowicy, u krów przed porodem około $74 \%$ i $80-85 \%$ w okresic laktacji. Stężenie frakcji lipoprotein o niskicj gęstości (LDL) było niższe; u krów zasuszonych wynosiło średnio 22\%, w 6-tym tygodniu laktacji 13-15\%. U krów przed porodem ponad 40\% lipidów LDL stanowiły trójgliceryờ (TG) i około $32 \%$ cholesterol. W szczycic laktacji udział TG w LDL obniżył sic̨ do $14-19 \%$, a choresterolu wzrósł do ponad $45 \%$. 